\title{
Antibody response in Staphylococcus aureus septicaemia - a prospective study
}

\author{
P. COLQUE-NAVARRO, B. SÖDERQUiST*, H. HOLMBERG*, L. BLOMOVIST, P. OLCÉN* \\ and R. MÖLLBY
}

Microbiology and Tumorbiology Center (MTC), Karolinska Institutet, Stockholm and * Department of Infectious Diseases and Department of Clinical Microbiology, Örebro Medical Center Hospital, Örebro, Sweden

\begin{abstract}
Formation of serum antibodies against $\alpha$-toxin, teichoic acid and lipase was followed in 63 patients with Staphylococcus aureus septicaemia in 240 consecutive serum samples. Control subjects comprised 23 patients with septicaemia due to other causes and 21 febrile patients without septicaemia. An antibody response against $\alpha$-toxin, measured by ELISA, was most common (40\%) in the initial serum, but antibody to teichoic acid was present in the highest number of positive patients $(60 \%)$ when samples were drawn between 0 and 30 days: $74 \%$ of the patients showed a positive antibody response to at least one of the three antigens. When complicated versus uncomplicated septicaemia was compared (samples taken 8-14 days), $14(45 \%)$ of 31 patients had a positive response against $\alpha$-toxin versus $12(75 \%)$ of 16, against teichoic acid $16(51 \%)$ of 31 versus 12 (75\%) of 16 and against lipase $15(48 \%)$ of 31 versus $8(50 \%)$ of 16. Patients with low initial antibody levels displayed a poorer antibody response than those with higher initial antibody levels. This phenomenon was observed with all three antigens, but was most pronounced with $\alpha$-toxin. The initial antibody levels may predict the antibody response during the course of the disease. ELISA titres against $\alpha$-toxin correlated $(r=0.87)$ with biological neutralising activity of the antisera. The results may indicate a biological role of serum antibodies in staphylococcal septicaemia.
\end{abstract}

\section{Introduction}

Septicaemia due to Staphylococcus aureus remains a common and serious disease with an increasing incidence [1] and a significant morbidity and mortality [2].

The need for improved methods to diagnose $S$. aureus septicaemia is evident, as the traditional blood culture methodology has some drawbacks - negative cultures may be a result of earlier antibiotic therapy or false positive cultures may be caused by contamination when blood samples are taken. Serological diagnosis provides an important complement to the diagnostic arsenal of the clinical laboratory. The use of serology to differentiate between complicated and uncomplicated $S$. aureus septicaemia [3] as well as to follow the effect of treatment has been suggested [4].

Received 1 May 1997; revised version accepted 20 July 1997.

Corresponding author: Dr P. Colque-Navarro.
Various serological tests for the diagnosis of serious $S$. aureus infections have used different cell components as antigens, such as cell membrane or cell-wall components, extracellular toxins or enzymes [5-8]. As most individuals have circulating antibodies against antigens from $S$. aureus $[6,9]$, serological diagnosis depends upon the detection of elevated antibody levels or of significant changes in antibody titres, i.e., 'seroconversion'. For this purpose, quantitative methods are required that display maximal reproducibility and accuracy taking into account the age-related normal values [10].

In Sweden, the neutralisation assay against 'staphylolysin', i.e., crude staphylococcal $\alpha$-toxin, has been in routine use for 50 years [11]. This test is now mostly replaced by an ELISA for the detection of serum antibodies against purified $\alpha$-toxin. Teichoic acid is used as a complementary antigen in the routine diagnosis of deep staphylococcal infections. In fact, detection of antibodies against staphylococcal teichoic acid may be used in screening for IgG2 deficiency [12]. Lipase has also been used as an antigen in staphylococcal serology [13]. 
This prospective study followed the kinetics of antibody production during staphylococcal septicaemia and compared individual responses to three different antigens, $\alpha$-toxin, teichoic acid and lipase. The aim was to follow the relationship between the clinical course and the antibody response, as well as the significance of the patient's initial antibody titres. The sensitivity and specificity of the three antigen tests, alone or in combination, were compared for their value in serological diagnosis.

\section{Materials and methods}

\section{Serum samples}

All serum samples were collected at the Department of Infectious Diseases, Örebro Medical Center Hospital as described previously [14]. Consecutive patients with verified $S$. aureus septicaemia were included without any selection. In total, 63 patients with septicaemia were followed with 240 consecutive serum samples. The mean age of the patients was 65 years (Fig. 1) and 59\% were male. The septicaemia was community acquired in 49 patients and in 14 cases septicaemia occurred during hospitalisation. Two patients were known drug addicts, none was HIVpositive.

The diagnosis of $S$. aureus septicaemia was verified by at least two positive blood cultures performed with the Bactec $660 \mathrm{HP}$ system (Becton Dickinson, USA). Complicated septicaemia was defined as a complicated clinical course with a septic metastasis, e.g., acute osteomyelitis, septic arthritis or extensive abscesses. Uncomplicated septicaemia was defined as septicaemia without a detectable infectious focus. Endocarditis was defined according to the strict case definition given by von Reyn [15]. Among the 63 patients, 43 were classified as complicated and 20 as uncomplicated cases of septicaemia. Fifteen patients fulfilled the criteria for endocarditis; one was definite, six were probable and eight were possible. The age distribution was similar (Fig. 1) with a slightly higher mean age among the patients with uncomplicated septicaemia.

Serum samples were taken on the day of admission, 3 days later and once a week thereafter as long as the patients were being monitored. Serum samples and $S$. aureus isolates from the blood cultures were stored at $-70^{\circ} \mathrm{C}$ until assayed. To simplify the analysis of the antibody response with respect to duration of illness, the time of serum sampling was categorised into four intervals: $0-7$ days $(n=50), 8-14$ days $(n=47), 15-$ 30 days $(n=37)$ and $>30$ days $(n=18)$ after onset of disease.

The control subjects comprised two groups, 23 patients suffering septicaemia caused by species other than $S$ aureus (nine patients with Streptococcus

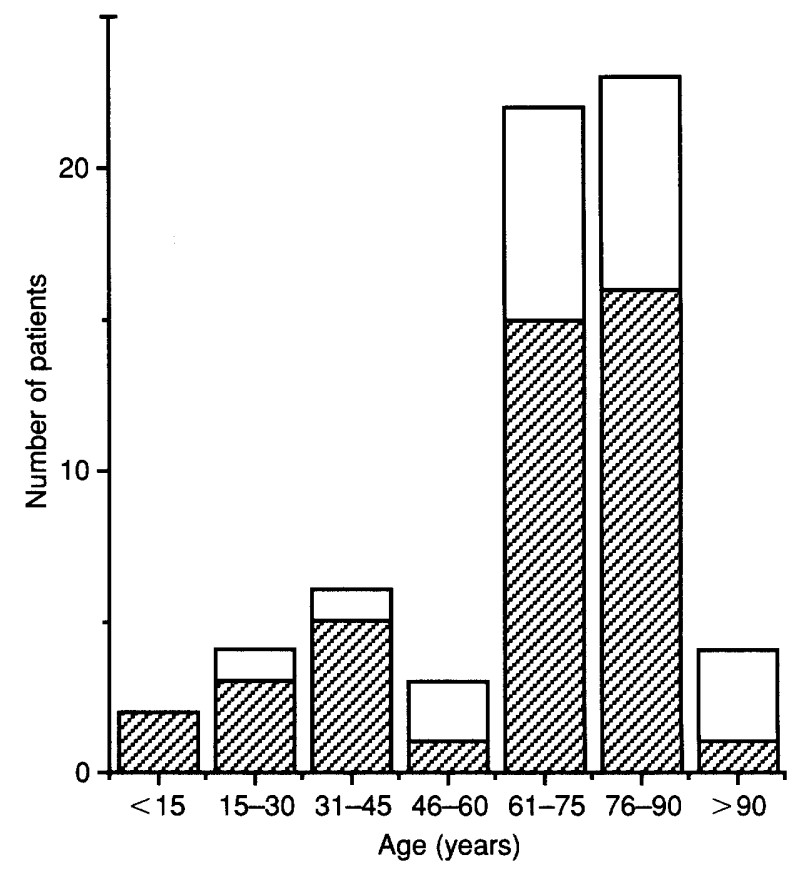

Fig. 1. Age distribution of patients with septicaemia; $\square$, patients with uncomplicated septicaemia; $\square$, complicated septicaemia.

pneumoniae, six with Escherichia coli, two with $S$. epidermidis, two with Klebsiella pneumoniae, one with Str. pyogenes, one with Enterobacter cloacae, one with $K$. oxytoca and one with Bacteroides fragilis) and comprising 70 serum samples, and 21 febrile patients with clinical signs suggesting septicaemia, but without positive blood culture and without local $S$. aureus infection, and comprising 49 serum samples. The mean age of this control population was 58 years. The diagnoses included extensive soft tissue infection $(\mathrm{n}=12)$ due to $S$. epidermidis, Str. pneumoniae, Str. pyogenes and E. coli, arthritis or osteomyelitis $(\mathrm{n}=4)$ caused by $S$. epidermidis, E. coli and Str. pygenes, pneumonia $(\mathrm{n}=3)$ due to Mycoplasma pneumoniae or influenza A virus and urinary tract infection $(\mathrm{n}=2)$ caused by $E$. coli.

\section{Staphylococcal antigens}

Purified lipase was kindly provided by Dr S. Tyski, Warzaw [16]. Highly purified commercial preparations of teichoic acid and $\alpha$-toxin belonging to the $S$. aureus serology kit were used (BioSys inova, Stockholm, Sweden).

\section{ELISA}

The ELISA procedure has been detailed previously [17]. Briefly, coating doses for the 96-well microtitration plates (Dynatech M-129B, Plochingen, Germany) with $\alpha$-toxin, teichoic acid and lipase were established at $2.5 \mu \mathrm{g} / \mathrm{ml}, 1 \mu \mathrm{g} / \mathrm{ml}$ and $2 \mu \mathrm{g} / \mathrm{ml}$, respectively. The working volume throughout the tests was $100 \mu \mathrm{l} /$ well. The microtitration plates were coated with antigens 
diluted in phosphate-buffered saline (PBS), $\mathrm{pH}$ 7.4, and incubated overnight at $22^{\circ} \mathrm{C}$. The plates were washed and a serum dilution in PBS with Tween-20 $0.05 \% \mathrm{v} / \mathrm{v}$ (PBS-T) of 1 in 1000 for $\alpha$-toxin and a 1 in 10000 for teichoic acid and lipase was added to two coated wells. Positive and negative controls were included in each plate. The plates were incubated for $1 \mathrm{~h}$ at room temperature $\left(20^{\circ} \mathrm{C}\right)$. After washing the plates, alkaline phosphatase-conjugated goat antihuman antibodies (Sigma) diluted in PBS-T was added to each well, and the plates were incubated for $2 \mathrm{~h}$ at room temperature. After the final wash $p$-nitrophenylphosphate substrate (Sigma) was added. Titres were read when the positive controls reached previously established values at $405 \mathrm{~nm}$ on a Titertek Multiskan (Flow Laboratories, Irvine) instrument.

All tests were performed in duplicate and mean values were calculated after deduction of the blank. All sera were tested at least twice.

\section{Interpretation of results}

The relative ELISA titre was defined as the $\mathrm{A}_{405}$ value multiplied by the serum dilution factor. Normal antibody titres were established previously in healthy controls. Age-related upper cut-off levels were set at the upper 95th percentile. Titre values above this cutoff level were considered as high. A significant rise in titre was defined as a two-fold increase compared to a previous sample. Positive serology was defined as a high titre in at least one serum sample or a significant rise in titre between two samples.

\section{Statistical methods}

Fisher's exact test and Student's $t$ test were performed with the computer program Statgraphics, version 2.6 (STSC, Street Rockville, USA).

\section{Neutralisation test}

A microscale neutralisation test based on the traditional anti-staphylolysin (ASTA) method [11] was developed and performed in polystyrene microtitration plates with purified $\alpha$-toxin according to Kanclerski and Möllby [18]. Briefly, $50 \mu \mathrm{l}$ of buffer (PBS-T) were added to all the wells of the microtitration plates; $50 \mu \mathrm{l}$ of patient serum samples diluted 1 in 6 in PBS-T were added to the first well of each row and two-fold dilutions were performed along the row with a volume of $50 \mu \mathrm{l}$. Next, $50 \mu \mathrm{l}$ of $\alpha$-toxin containing $5 \mathrm{HU} / \mathrm{ml}$ were added to each well. After incubation for $30 \mathrm{~min}$ at $37^{\circ} \mathrm{C}, 100 \mu \mathrm{l}$ of rabbit erythrocyte suspension (1\%) were added to each well and incubated for $75 \mathrm{~min}$ at $37^{\circ} \mathrm{C}$. In each run a control for the haemolytic activity of $\alpha$-toxin and a control for the rabbit erythrocyte suspension was performed, a known positive and negative patient serum control were included. After resuspension of erythrocytes and careful removal of surface air bubbles, the reaction was read spectrophotometrically at $620 \mathrm{~nm}$ and quantitative interpretation of the results was done by interpolation. One haemolytic unit (HU) was defined as the amount of $\alpha$-toxin present in the dilution that resulted in lysis of $50 \%$ of the erythrocytes in the well [18].

\section{Results \\ Kinetics of the antibody response}

The kinetics of the antibody response to the three different antigens varied greatly between different patients (Fig. 2). Patient A was of special interest because he had recurrent infections, which are reflected in the appearance of secondary peaks at days 29 and 85 . Patient $F$ represents the extreme case in which no antibody response at all was detected, while the other patients showed common patterns of response.

\section{Antibody response to each of the three antigens}

The percentage of patients showing a positive antibody response to $\alpha$-toxin, teichoic acid and lipase from $S$. aureus used as single antigens is shown in Table 1 . In the early stage of illness, positive titres against $\alpha$-toxin were most common $(40 \%)$, but antibody response to teichoic acid was found in the highest number of patients $(60 \%)$ when serum samples were taken between 8 and 14 (and up to 30) days.

In the control group of patients with septicaemia caused by agents other than $S$. aureus, the antibody levels were found to be above the upper limits set for healthy controls against $\alpha$-toxin (four patients), teichoic acid (five) and lipase (five). The corresponding figures for the control group with fever caused by agents other than $S$. aureus were two patients with raised antibody levels against $\alpha$-toxin, three against teichoic acid and three against lipase. Taking both control groups together, high levels of antibodies against $\alpha$-toxin or teichoic acid, or both, were found in 10 of 44 patients, but in no case there was a rise in titre during the disease.

\section{Combinations of antigens}

Combination of the ELISA results obtained with the three antigens in parallel showed that $74 \%$ of all $S$. aureus septicaemia patients gave positive serological results against at least one antigen (8-30 days) (Table 2 ). The use of $\alpha$-toxin and teichoic acid appeared to be sufficient for diagnostic purposes, as the addition of lipase as a third antigen did not increase the number of positive patients. However, it should be noted that $25 \%$ of the patients did not respond to any of the antigens during up to 30 days of disease. 

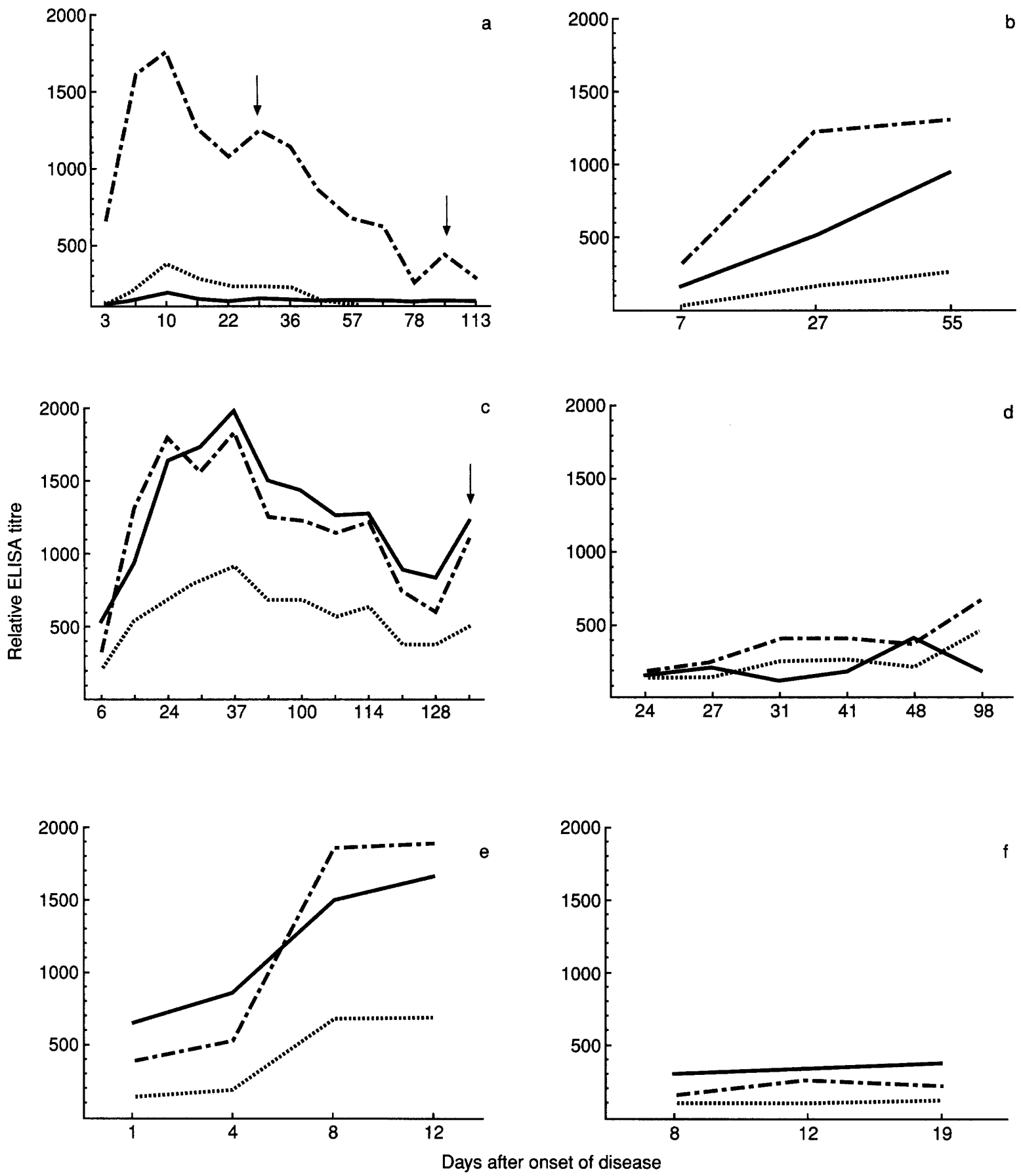

Fig. 2. Kinetics of the antibody response against three antigens in patients with $S$. aureus septicaemia. a-f depict individual patients; _ IgG titres against $\alpha$-toxin; - - - IgG titres against teichoic acid and $\cdots . .$. against lipase. Patients b-e responded fairly well but at different times and to different antigens; patient a responded mainly to teichoic acid, also in the two relapses (arrows); patient $\mathbf{f}$ did not respond at all to the three antigens investigated.

\section{Neutralising antibodies against $\alpha$-toxin}

There was a close correlation between ELISA titres and neutralisation titres against $\alpha$-toxin ( $\mathrm{r}=0.87$ ) (Fig. 3). This finding indicates a biological role of the antibody levels measured in the ELISA.

\section{Initial antibody status}

Patients with low initial antibody levels showed a weaker antibody response than those with higher initial levels. This phenomenon was observed with all three antigens, but was most pronounced with $\alpha$-toxin (Fig. 4). Here only two of 13 patients with initially low titres $(<200)$ showed a positive antibody response, while 14 of 18 patients with initial titres $>400$ showed a positive response $(p=0.0009)$. It should be noted that 11 of the 13 patients with low initial antibody levels developed complicated septicaemia.

Antibody response in patients with complicated versus uncomplicated septicaemia

The antibody response was weaker in patients with 
Table 1. Comparison of IgG response against $\alpha$-toxin, teichoic acid and lipase as single antigens in patients with staphylococcal septicaemia at different times after onset of disease

\begin{tabular}{lcccc}
\hline & \multicolumn{4}{c}{ Number (\%) of patients with a positive antibody response } \\
\cline { 2 - 5 } & $0-7$ days & $8-14$ days & $15-30$ days & $>30$ days \\
$(\mathrm{n}=50)$ & $(\mathrm{n}=37)$ & $(\mathrm{n}=18)$ \\
Antibody response & & $14(30)$ & $9(24)$ & $3(17)$ \\
\hline$\alpha$-toxin & $20(40)$ & $12(26)$ & $10(27)$ & $8(44)$ \\
$\quad$ High titre & 0 & 0 & $1(3)$ & $1(6)$ \\
High titre with rise & 0 & $26(55)$ & $20(54)$ & $12(67)$ \\
Rise only & $20(40)$ & $14(30)$ & $10(27)$ & $7(39)$ \\
$\quad$ Total positive & $13(26)$ & $10(21)$ & $9(24)$ & $4(22)$ \\
Teichoic acid & $1(2)$ & $4(9)$ & $3(8)$ & $1(6)$ \\
$\quad$ High titre & $1(2)$ & $28(60)$ & $22(59)$ & $12(67)$ \\
High titre with rise & $15(30)$ & $13(28)$ & $10(27)$ & $6(33)$ \\
Rise only & $11(22)$ & $8(17)$ & $6(16)$ & $4(22)$ \\
Total positive & 0 & $23(4)$ & $1(3)$ & 0 \\
Lipase & $1(2)$ & $23(49)$ & $17(46)$ & $10(55)$ \\
$\quad$ High titre & $12(24)$ & &
\end{tabular}

Significant rises are calculated in relation to the first available serum

Table 2. Serum IgG response against $\alpha$-toxin, teichoic acid and lipase and combinations of these in patients with staphylococcal septicaemia

\begin{tabular}{lcccc}
\hline & \multicolumn{4}{c}{ Number (\%) of patients with a positive antibody response } \\
\cline { 2 - 5 } & $\begin{array}{c}0-7 \text { days } \\
(\mathrm{n}=50)\end{array}$ & $\begin{array}{c}8-14 \text { days } \\
(\mathrm{n}=47)\end{array}$ & $\begin{array}{c}15-30 \text { days } \\
(\mathrm{n}=37)\end{array}$ & $\begin{array}{c}>30 \text { days } \\
(\mathrm{n}=18)\end{array}$ \\
\hline Test antigens & $5(10)$ & $13(28)$ & $11(30)$ & $8(44)$ \\
All three antigens & $8(16)$ & $16(34)$ & $10(27)$ & $3(17)$ \\
Two antigens* & $11(22)$ & $3(6)$ & $2(5)$ & $2(11)$ \\
$\alpha$-toxin alone & $5(10)$ & $3(6)$ & $4(11)$ & $1(6)$ \\
Teichoic acid alone & 0 & 0 & 0 & $1(6)$ \\
Lipase alone & $29(58)$ & $35(74)$ & $27(73)$ & $15(83)$ \\
Any antigen & $29(58)$ & $35(74)$ & $27(73)$ & $13(72)$ \\
$\alpha$-toxin and teichoic & & & & \\
acid $\dagger$ & $24(48)$ & $32(68)$ & $23(62)$ & $13(72)$ \\
$\alpha$-toxin and lipase $\dagger$ & $18(36)$ & $32(68)$ & $25(68)$ & $12(67)$ \\
Teichoic acid and lipase $\dagger$ &
\end{tabular}

*Any combination: both antigens should be positive.

†One or both of the two antigens in the combination should be positive.

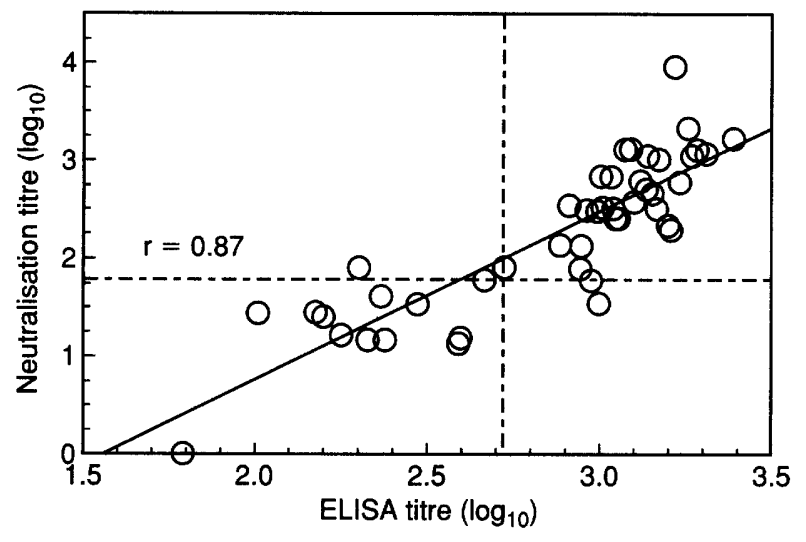

Fig. 3. Comparison of serum antibody levels against $\alpha$ toxin as measured by neutralisation titres or by ELISA. Vertical and horizontal dotted lines indicate the respective cut off limits for adults.

complicated than in those with uncomplicated septicaemia. In patients with uncomplicated septicaemia, the percentage with a positive antibody response increased from $38 \%$ to $75 \%$ with $\alpha$-toxin, from $25 \%$ to $75 \%$ with teichoic acid and with lipase from $13 \%$ to $50 \%$ (Table 3 ) from the first time interval ( $0-7$ days) to the second (8-14 days). In patients with complicated septicaemia these increases were smaller, especially for $\alpha$-toxin, where the increase was only from $41 \%$ to $45 \%$.

Thus, the antibody response against $\alpha$-toxin during the first days of illness differed between complicated and uncomplicated septicaemia. There was a marked difference in the mean rise in titre (200 versus 500 , $\mathrm{p}=0.06$ ) and the number of positive patients differed significantly (16 of 32 versus 14 of $16, p=0.025$ ) (Table 4).

Patients with complicated and uncomplicated septicaemia also differed in the type of antibody response; complicated septicaemia patients more often had a relatively constant high titre than an increasing response during the disease, when compared to patients with uncomplicated septicaemia (Table 4). For $\alpha$-toxin, the number of patients with only high 

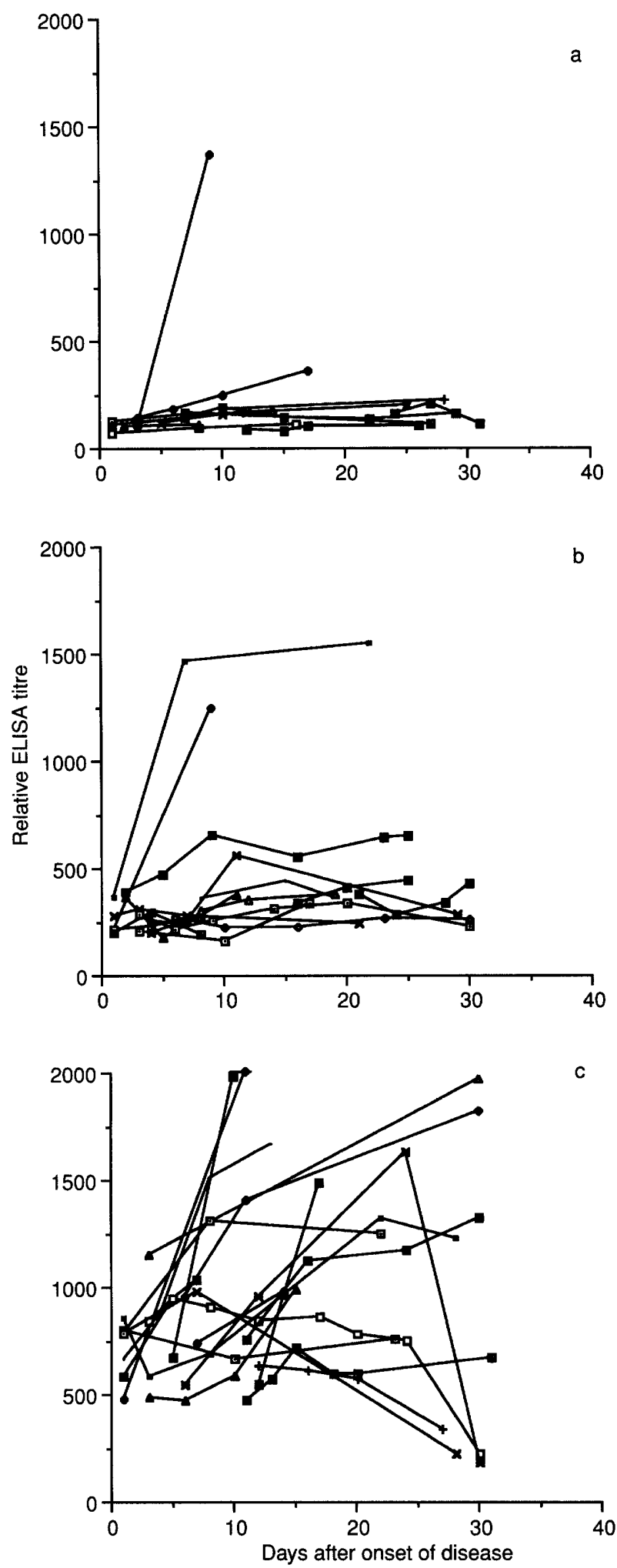

Fig. 4. IgG antibody titres against $\alpha$-toxin: relationships between initial titres and antibody response during disease. A, patients with initially low titres $(<200)$; B, patients with initial intermediate titres $(200-400)$; C, patients with initial high titres $(>400)$. Each line represents one patient.

titres were 10 of 32 positive as compared to 4 of 16 $(\mathrm{p}=0.7$, n.s.) and with any increase in titre, six of 32 positive as compared to 10 of $16(p=0.004)$. This difference in antibody response against lipase was significant $(p=0.018)$. There was a similar but not significant response to teichoic acid. Patients with endocarditis showed an antibody response of the same magnitude as the patients with complicated septicaemia.

Combined analysis of the response to all three antigens showed that $88 \%$ of the patients with uncomplicated septicaemia gave positive results whereas in those with complicated septicaemia, only $68 \%$ responded (Table 5). $\alpha$-Toxin alone was found to contribute to the positive response in $44 \%$ of the early samples, i.e., antibodies were produced against only $\alpha$ toxin and not against the other two antigens in 7 of 16 patients with uncomplicated septicaemia sampled within 8 days of the onset of disease.

\section{Antibody titres}

Convalescent (8-30 days) sera from patients with complicated septicaemia showed lower titres against $\alpha$-toxin than samples from patients with uncomplicated septicaemia (789 versus $1208, p=0.06)$, although the mean titres were the same in the acute phase (0-7 days) (Table 6). It is evident that the increases in mean titre against $\alpha$-toxin and against lipase were lower in patients with complicated septicaemia than in patients with uncomplicated septicaemia. However, antibodies against teichoic acid increased similarly in both groups.

\section{Discussion}

The sera collected in this study allowed the study of the kinetics of the antibody response in patients suffering from $S$. aureus septicaemia. It was obvious that patients showed individual variation in their response to different antigens. Similar observations have been made by others [19-21]. Thus, in order to obtain an optimal diagnostic test with maximal sensitivity, it is preferable to use two or more antigens in parallel, when an antibody rise (or high titre) to either one of the antigens is enough to be considered as a positive response. To further optimise the diagnostic assay, it is important to standardise the assay carefully by including highly purified antigens and well characterised reference sera.

In the present study, the optimal antigen combination for diagnostic purposes was found to be $\alpha$-toxin and teichoic acid (Table 2). However, lipase has been suggested for use as a single protein antigen for diagnostic purposes in $S$. aureus septicaemia [13]. In the present study, antibody to lipase was found in fewer patients that to the other antigens (Table 1), and in only one serum was anti-lipase the only antibody found (Table 2).

Anti-lipase antibody was most commonly found in the 
Table 3. Serum IgG response against $\alpha$-toxin, teichoic acid and lipase as single antigens in patients with uncomplicated $(U)$ and complicated $(C)$ staphylococcal septicaemia

\begin{tabular}{|c|c|c|c|c|c|c|}
\hline \multirow[b]{3}{*}{ Antibody response } & \multicolumn{6}{|c|}{ Percentage of patients with a positive antibody response } \\
\hline & \multicolumn{2}{|c|}{$0-7$ days } & \multicolumn{2}{|c|}{$8-14$ days } & \multicolumn{2}{|c|}{$15-30$ days } \\
\hline & $U(n=16)$ & $C(n=34)$ & $\mathrm{U}(\mathrm{n}=16)$ & $C(n=31)$ & $U(n=12)$ & $C(n=25)$ \\
\hline \multicolumn{7}{|l|}{$\alpha$-toxin } \\
\hline High titre & 38 & 41 & 38 & 26 & 25 & 24 \\
\hline High titre with rise & 0 & 0 & 38 & 19 & 42 & 20 \\
\hline Rise only & 0 & 0 & 0 & 0 & 8 & 0 \\
\hline Total positive & 38 & 41 & 76 & 45 & 75 & 44 \\
\hline \multicolumn{7}{|l|}{ Teichoic acid } \\
\hline High titre & 25 & 29 & 25 & 32 & 33 & 24 \\
\hline High titre with rise & 0 & 3 & 31 & 16 & 25 & 24 \\
\hline Rise only & 0 & 0 & 19 & 3 & 17 & 4 \\
\hline Total positive & 25 & 32 & 75 & 51 & 75 & 52 \\
\hline \multicolumn{7}{|l|}{ Lipase } \\
\hline High titre & 13 & 29 & 19 & 32 & 25 & 28 \\
\hline High titre with rise & 0 & 0 & 25 & 13 & 25 & 12 \\
\hline Rise only & 0 & 0 & 6 & 3 & 8 & 0 \\
\hline Total positive & 13 & 29 & 50 & 48 & 58 & 40 \\
\hline
\end{tabular}

Table 4. Positive serum $\operatorname{IgG}$ response at any paired sampling time between 0 and 30 days after onset of disease against $\alpha$-toxin, teichoic acid and lipase as single antigens and combinations of these

\begin{tabular}{|c|c|c|}
\hline \multirow[b]{2}{*}{ Antibody response } & \multicolumn{2}{|c|}{$\begin{array}{l}\text { Number (\%) of patients with a positive } \\
\text { antibody response }\end{array}$} \\
\hline & $\begin{array}{l}\text { Complicated sepsis } \\
\qquad(\mathrm{n}=32)\end{array}$ & $\begin{array}{l}\text { Uncomplicated sepsis } \\
\qquad(\mathrm{n}=16)\end{array}$ \\
\hline \multicolumn{3}{|l|}{$\alpha$-toxin } \\
\hline High titre & $10(31)$ & $4(25)$ \\
\hline High titre with rise & $5(16)$ & $9(56)$ \\
\hline Rise only & $1(3)$ & $1(6)$ \\
\hline Total positive & $16(50)$ & $14(88)$ \\
\hline \multicolumn{3}{|l|}{ Teichoic acid } \\
\hline High titre & $11(34)$ & $4(25)$ \\
\hline High titre with rise & $7(22)$ & $5(31)$ \\
\hline Rise only & $1(3)$ & $4(25)$ \\
\hline Total positive & $19(59)$ & $13(81)$ \\
\hline \multicolumn{3}{|l|}{ Lipase } \\
\hline High titre & $12(38)$ & $2(13)$ \\
\hline High titre with rise & $2(6)$ & $6(38)$ \\
\hline Rise only & $3(9)$ & $2(6)$ \\
\hline Total positive & $17(53)$ & $10(63)$ \\
\hline
\end{tabular}

two control groups, thus suggesting low specificity. Therefore, we conclude that under these conditions, the use of lipase in addition to $\alpha$-toxin and teichoic acid antigens would not increase the diagnostic value of the test.

Approximately $25 \%$ of the septicaemic patients did not react to any of the antigens (Table 3) during 30 days from onset of disease. To explain the absence of any antibody response, the isolated strains were examined for $\alpha$-toxin production in a haemolytic assay and in an antigen-ELISA. All strains produced $\alpha$-toxin in vitro, although to a varying extent [17]. This finding is in contrast to several earlier studies in which different strain collections of various origins have been reported to produce $\alpha$-toxin in vitro at highly varying frequencies [22]. Furthermore, the production of other toxins such as enterotoxins A-D and toxic shock syndrome toxin 1 (TSST-1), that could have exhibited superantigenic immunomodulat-

Table 5. Antibody response detected in paired (early and late) samples against $\alpha$-toxin, teichoic acid and lipase and combinations of them in patients with uncomplicated and complicated staphylococcal sepsis; percentage of positive patients is given

\begin{tabular}{|c|c|c|c|c|c|c|}
\hline \multirow[b]{3}{*}{ Test antigens } & \multicolumn{6}{|c|}{ Number of patients with a positive antibody response } \\
\hline & \multicolumn{2}{|c|}{$0-7$ days } & \multicolumn{2}{|c|}{$8-14$ days } & \multicolumn{2}{|c|}{$15-30$ days } \\
\hline & $U(n=16)$ & $C(n=34)$ & $\mathrm{U}(\mathrm{n}=16)$ & $C(n=31)$ & $\mathrm{U}(\mathrm{n}=12)$ & $C(n=25)$ \\
\hline All three antigens & 0 & 15 & 31 & 26 & 50 & 20 \\
\hline Any of two antigens & 13 & 15 & 50 & 26 & 25 & 28 \\
\hline$\alpha$-toxin alone & 44 & 12 & 13 & 6 & 0 & 8 \\
\hline Teichoic acid alone & 13 & 9 & 0 & 10 & 8 & 12 \\
\hline Lipase alone & 0 & 0 & 0 & 0 & 0 & 0 \\
\hline Any antigen & 69 & 53 & 88 & 68 & 83 & 68 \\
\hline No antigen & 31 & 47 & 13 & 32 & 17 & 32 \\
\hline$\alpha$-toxin + teichoic acid & 69 & 53 & 88 & 68 & 83 & 68 \\
\hline$\alpha$-toxin + lipase & 56 & 44 & 88 & 58 & 75 & 56 \\
\hline Teichoic acid + lipase & 25 & 41 & 81 & 61 & 83 & 60 \\
\hline
\end{tabular}

U, uncomplicated septicaemia; C, complicated septicaemia. 
Table 6. Comparison of antibody titres against $\alpha$-toxin, lipase and teichoic acid in patients with septicaemia

\begin{tabular}{llccc}
\hline & \multicolumn{4}{c}{ Mean (SEM) titre in patients with } \\
\cline { 2 - 5 } Serum & Test & $\begin{array}{c}\text { Complicated sepsis } \\
(\mathrm{n}=29)\end{array}$ & $\begin{array}{c}\text { Uncomplicated sepsis } \\
(\mathrm{n}=13)\end{array}$ \\
\hline antigen & $520(94)$ & $512(93)$ & \\
& $\alpha$-toxin & $2300(383)$ & $1477(266)$ & $\mathrm{p}=0.18$ \\
& Lipase & $5316(721)$ & $3678(566)$ & $\mathrm{p}=0.16$ \\
& Teichoic acid & $789(119)$ & $1208(179)$ & $\mathrm{p}=0.06$ \\
& $\alpha$-toxin & $3220(429)$ & $4338(735)$ & $\mathrm{p}=0.17$ \\
& Lipase & $9039(1100)$ & $8017(1297)$ & \\
\hline
\end{tabular}

ing activities, was not related to the antibody response, and could not explain the lack of antibody response in certain patients. Neither did these patients show a decreased immune response to enterotoxin $\mathrm{A}$ or TSST-1 [23].

It has been suggested that the antibody levels could be used to follow the clinical course of deep $S$. aureus infections [24-27], but this clinical use of staphylococcal serology has not as yet been properly evaluated [28]. However, in the present study two patients were followed after their initial disease, and it was clearly seen that the antibody levels fell slowly upon recovery (Fig. 2A). When the patients relapsed with staphylococcal infections, this was clearly seen as minor secondary peaks. Thus, for patients with a positive response, serology might be used for monitoring the course of recovery.

It was found that patients who developed complicated septicaemia had a lower antibody response, especially against $\alpha$-toxin, than patients with uncomplicated septicaemia (Table 3). This difference was evident both when calculated as mean antibody levels on days 8-14 and as number of patients with positive serology. This finding is in direct contrast to those of many other studies, in which complicated septicaemias were reported to result in higher antibody responses [3, 25]. In fact, the use of teichoic acid as antigen in serological diagnosis has been suggested for the discrimination of uncomplicated from complicated septicaemia [4, 29].

An explanation for this contradiction may be the fact that earlier studies were performed in 1970-1980 and most of the patients selected were young drug abusers, who may have had a special inmunological status because of their repeated exposure to $S$. aureus and other foreign antigens. The present investigation is based upon a truly consecutive series of patients, whereas many other studies may have been based upon selected patient populations.

Furthermore, if the protective effects of the immune system are to be considered for deep staphylococcal infections, it is reasonable to envisage that patients with a more active immune response get fewer complications. It is also accepted that $S$. aureus is readily phagocytosed in the presence of adequate amounts of appropriate antibodies [30].

Of special interest was the relationship between low initial antibody levels against $\alpha$-toxin and the weak or absent antibody response to both protein antigens during disease, as is shown for $\alpha$-toxin in Fig. 4 . These findings indicate that certain patients have a weaker antibody response than others, and that this may be suspected from their acute phase antibody levels.

The initial antibody levels seemed to influence the course of the disease, as 11 of 13 patients with low initial antibody titres against $\alpha$-toxin developed a complicated septicaemia. It could be argued that the average age of the patients studied was high and that elderly patients would show a weaker immune response, but actually the younger patients developed complicated septicaemia at the same or at a higher frequency than the elderly (Fig. 1).

The antibody response and its relation to the course of the disease has been described before. Christensson and co-workers [31] reported that patients suffering from TSS had no antibody against the TSS-toxin. Patients suffering chronic mandibulitis had lower IgG2 levels than the normal population [32]. Furthermore, a correlation between serum antibody titres and the course of the disease has been demonstrated for other bacteria colonising healthy individuals, e.g., between antibodies to Clostridium difficile cytotoxin and the patient's capacity to recover from relapsing diarrhoeal episodes [33] and between serum antibodies to streptococcal toxins and fatal outcome in streptococcal septicaemia [34].

The antibody response in the septicaemia patients negative for $S$. aureus was unexpectedly high for all three antigens. This finding might be explained by possible polyclonal activation or remaining titres from previous $S$. aureus infections, as none of these patients showed a rise in titre, but a constant high antibody level. The possibility of mixed infections, where the $S$. aureus was not detected, cannot be excluded. 
In summary, the antibody response varied considerably between individuals. There appears to be a correlation between a weak antibody response in the acute phase and the further development of antibodies during the disease, as well as with the course of the disease. Thus, these findings indicate a protective role for the immune response and the possible use of future immunoprophylaxis and therapy of serious staphylococcal infections.

Today, staphylococcal serology is used by clinicians mainly for confirmation, but in future it may also be used to monitor treatment, detect relapse or re-infection and to make an early identification of patients at high risk.

\section{References}

1. Frimodt-Möller N, Espersen F, Rosdahl VT, Bentzon MW, Skinhöj P. Epidemiological aspects of Staphylococcus aureus in Denmark during 30 years from 1957-1987. In: Möllby R, Flock JI, Nord CE Christensson B (eds) Staphylococci and staphylococcal infections. Stuttgart, Gustav Fishers Verlag. 1994; 9-11.

2. Shah M, Watanakunakorn C. Changing patterns of Staphylococcus aureus bacteremia. Am J Med Sci 1979; 278: 115-121.

3. Verbrugh HA, Peters R, Goessens WHF, Michel MF. Distinguishing complicated from uncomplicated bacteremia caused by Staphylococcus aureus: the value of 'new' and 'old' serological tests. J Infect Dis 1986; 153: 109-115.

4. Wheat J, Kohler RB, White A, Garten M. IgM and IgG antibody response to teichoic acid in infections due to Staphylococcus aureus. J Infect Dis 1983; 147: 1101.

5. Christensson B, Hedström SÅ, Kronvall G. Antibody response to alpha- and beta-hemolysin from Staphylococcus aureus in patients with staphylococcal infections and in normals. Acta Pathol Microbiol Immunol Scand Sect B 1983; 91: 351-356.

6. Granström M, Julander I, Möllby R. Serological diagnosis of deep Staphylococcus aureus infections by enzyme-linked immunosorbent assay for staphylococcal hemolysins and teichoic acid. Scand J Infect Dis 1983; Suppl 41: 132-135.

7. Herzog C, Wood H, Noel I, Booth J. Comparison of a new enzyme-linked immunosorbent assay method with counterimmunoelectrophoresis for detection of teichoic acid antibodies in sera from patients with Staphylococcus aureus infections. $J$ Clin Microbiol 1984; 19: 511-515.

8. Christensson B, Boutonnier A, Ryding U, Fournier J-M. Diagnosing Staphylococcus aureus endocarditis by detecting antibodies against $S$. aureus capsular polysaccharide types 5 and 8. $J$ Infect Dis 1991; 163: 530-533.

9. Bell JA, Pennington TH, Petrie DT. Western blot analysis of staphylococcal antibodies present in human sera during health and disease. $J$ Med Microbiol 1987; 23: 95-99.

10. Reizenstein E, Hallander HO, Blackwelder WC, Kuhn I, Ljungman M, Möllby R. Comparison of five calculation modes for antibody ELISA procedures, using pertussis serology as a model. J Immunol Methods 1995; 183: 279-290.

11. Packalen T, Bergquist. Staphylococci in throat and nose and antistaphylolysin titre. Acta Med Scand 1947; 127: 291-295.

12. Hammarström L, Granström M, Möllby R, Oxelius V, Persson MA, Smith CI. Ontogeny of IgG2 antibodies against $S$. aureus teichoic acid in normal and inmunodeficient children. Acta Paediatr Scand 1985; 74: 126-130.

13. Christensson B, Fehrenbach FJ, Hedström SÅ. A new serological assay for Staphylococcus aureus infections: detection of IgG antibodies to $S$. aureus lipase with an enzymelinked immunosorbent assay. J Infect Dis 1985; 152: 286-292.

14. Söderquist B. Staphylococcus aureus septicaemia. Aspects of exotoxins and the immune response. $\mathrm{PhD}$ thesis, Karolinska
Institute, Stockholm, Sweden, 1995.

15. von Reyn CF, Levy BS, Arbeit RD, Friedland G, Crumpacker CS. Infective endocarditis: an analysis based on strict case definitions. Ann Intern Med 1981; 94: 505-518.

16. Tyski S, Hryniewicz W, Jeljaszewicz J. Purification and some properties of the staphylococcal extracellular lipase. Biochim Biophys Acta 1983; 749: 312-317.

17. Söderquist B, Colque-Navarro $P$, Blomqvist L, Olcén $P$, Holmberg H, Möllby R. Staphylococcal $\alpha$-toxin in septicaemic patients; detection in serum, antibody response and production in isolated strains. Serodiagn Immunother Infect Dis 1993; 5: $139-144$.

18. Kanclerski K, Möllby R. A simple and exact two-point interpolation method for determination of haemolytic activity in microtiter plates. Acta Pathol Microbiol Immunol Scand Sect B 1987; 95: 175-179.

19. Christensson B, Espersen F, Hedström SA, Kronvall G. Serological assays against Staphylococcus aureus peptidoglycan, crude staphylococcal antigen and staphylolysin in the diagnosis of serious $S$. aureus infections. Scand J Infect Dis 1985; 17: 47-53.

20. Julander IG, Granström M, Hedström SÅ, Möllby R. The role of antibodies against alpha-toxin and teichoic acid in diagnosis of staphylococcal infections. Infection 1983; 11: 77-83.

21. Tyski S, Colque-Navarro P, Hryniewicz W, Granström M, Möllby R. Lipase versus teichoic acid and alpha-toxin as antigen in an enzyme immunoassay for serological diagnosis of Staphylococcus aureus infections. Eur J Clin Microbiol Infect Dis 1991; 10: 447-449.

22. Christensson B, Hedström SA. Biochemical and biological properties of Staphylococcus aureus septicemia strains in relation to clinical characteristics. Scand J Infect Dis 1986; 18: $297-303$.

23. Kanclerski K, Söderquist B, Kjellgren M, Holmberg H, Möllby R. Serum antibody response to Staphylococcus aureus enterotoxins and TSST-1 in patients with septicaemia. $J \mathrm{Med}$ Microbiol 1996; 44: 171-177.

24. Ericsson A, Granström M, Möllby R, Strandvik B. Antibodies to staphylococcal teichoic acid and alpha toxin in patients with cystic fibrosis. Acta Paediatr Scand 1986; 75: 139-144.

25. Dziarski R. Antibody responses to Staphylococcus aureus cell wall antigens. Clin Immunol 1985; 6: 58-64.

26. Herzog $\mathrm{CH}$, Berger R, Erb P, Hersperger S, Moldovany A. Serological evaluation of Staphylococcus aureus bacteremia in 136 patients: whole cell EIA ( $S$. aureus E 1369) versus immunodifusion (Endo-Staph). Proceedings of the 8th International Symposium. Aix-Les Bains, France, 1996: O-25.

27. Nagel JG, Tuazon CU, Cardella TA, Sheagren JN. Teichoic acid serologic diagnosis of staphylococcal endocarditis. Use of gel diffusion and counterimmunoelectrophoretic methods. Ann Intern Med 1975; 82: 13-17.

28. Möllby R. The antibody response in staphylococcal infections: diagnostic and therapeutic applications. The staphylococci. Zentralbl Backteriol 1991; Suppl 21: 61-68.

29. Tuazon CU, Sheagren JN. Techoic acid antibodies in the diagnosis of serious infections with Staphylococcus aureus. Ann Intern Med 1976; 84: 543-546.

30. Roitt IM. Essential immunology, 6th edn. Oxford, Blackwell Scientific Publications. 1988: 154-158.

31. Christensson $B$, Hedström SA. Serological response to toxic shock syndrome toxin in Staphylococcus aureus infected patients and in healthy controls. Acta Pathol Microbiol Immunol Scand Sect B 1985; 93: 87-90.

32. Nordin U, Wannfors K, Colque-Navarro P, Möllby R, Heimdahl A. Antibody response in patients with osteomyelitis of the mandible. Oral Surg Oral Med Oral Pathol Oral Radiol Endod 1995; 79: 429-435.

33. Aronsson B, Granström M, Möllby R, Nord CE. Serum antibody response to Clostridium difficile toxins in patients with Clostridium difficile diarrhoea. Infection 1985; 13: 97101.

34. Norrby-Teglund A, Kaul R, Low DE et al. Evidence for the presence of streptococcal-superantigen-neutralizing antibodies in normal polyspecific immunoglobulin G. Infect Immun 1996; 64: $5395-5398$. 